\title{
A comparative study of soil-water characteristic curves for compacted lateritic soil - bacillus coagulans mixtures
}

\author{
Kolawole Juwonlo Osinubi ${ }^{1}$, Paul Yohanna $^{2}$, Adrian Oshioname Eberemu ${ }^{1 *}$ and Thomas Stephen Ijimdiya ${ }^{1}$ \\ ${ }^{1}$ Civil Engineering Department, Ahmadu Bello University, Zaria, Nigeria \\ ${ }^{1 *}$ Civil Engineering Department and Africa Centre of Excellence on New pedagogies in Engineering Education, Ahmadu Bello \\ University, Zaria, Nigeria \\ ${ }^{2}$ Civil Engineering Department, University of Jos, Nigeria
}

\begin{abstract}
A comparative study of soil-water characteristic curves (SWCCs) for compacted lateritic soil - Bacillus coagulans (B. coagulans) mixtures for municipal solid waste (MSW) application was studied. Soil treatment was performed at approximately about one-third pore volume of the microbes (i.e., B. coagulans) for suspension densities of $0,1.5 \times 10^{8}, 6.0 \times 10^{8}, 1.2 \times 10^{9}, 1.8 \times 10^{9}$ and $2.4 \times 10^{9} \mathrm{cells} / \mathrm{ml}$, correspondingly. Soil specimens were prepared at optimum moisture content (OMC) of British Standard light (BSL) compaction energy. Cementation reagent was applied on the compacted soil and permitted to penetrate until partial saturation was achieved. A set-up of pressure plate extractor was employed to measure the volumetric water content, $\theta$ (VWC) in the laboratory for varying matric suctions with a minimum of $10 \mathrm{kPa}$ up to a maximum of $1,500 \mathrm{kPa}$. The unsaturated hydraulic conductivity (UHC) and VWC were assessed using Brooks - Corey (BC) and Fredlund - Xing (FX) models. Largely, BC and FX models overrated the VWC. Also, the VWC decreased with higher matric suction for the two models considered and the laboratory measured values. The UHC predicted for matric suctions of 500 and $1,500 \mathrm{kPa}$ initially decreased for B. coagulans suspension density up to $1.2 \times 10^{9}$ cells $/ \mathrm{ml}$ for $\mathrm{BC}$ and FX models, with the exception of a few cases, but thereafter increased with increase in microbial density. For FX model at 1,500 $\mathrm{kPa}$, UHC values of $2.42 \times 10^{-9}, 2.02 \times 10^{-9}, 9.31 \times 10^{-10}, 8.09 \times 10^{-10}, 1.29 \times 10^{-9}$ and $2.27 \times 10^{-9} \mathrm{~m} / \mathrm{s}$ were recorded at $0,1.5 \times 10^{8}, 6.0 \times 10^{8}$, $1.2 \times 10^{9}, 1.8 \times 10^{9}$ and $2.4 \times 10^{9} \mathrm{cells} / \mathrm{ml}$, respectively. In the case of BC model, values of $2.26 \times 10^{-17}, 1.41 \times 10^{-14}, 2.2 \times 10^{-14}, 4.6 \times 10^{-19}$, $3.25 \times 10^{-17}$ and $2.45 \times 10^{-14} \mathrm{~m} / \mathrm{s}$ were recorded at $0,1.5 \times 10^{8}, 6.0 \times 10^{8}, 1.2 \times 10^{9}, 1.8 \times 10^{9}$ and $2.4 \times 10^{9} \mathrm{cells} / \mathrm{ml}$, respectively. Thus, the FX model met the design maximum hydraulic conductivity value of $1 \times 10^{-9} \mathrm{~m} / \mathrm{s}$ requirement for MSW system when lateritic soil was treated with B. coagulans suspension density of $1.2 \times 10^{9}$ cells $/ \mathrm{ml}$, while the $\mathrm{BC}$ model satisfied the requirement for all the microbial densities considered and it is recommended for modelling of UHC of lateritic soil admixed with B. coagulans for MSW containment application.
\end{abstract}

Keywords: Bacillus coagulans, Brooks - Corey model, Fredlund -Xing model, Lateritic soil, Unsaturated hydraulic conductivity, Volumetric water content.

\section{Introduction}

The study of soil-water behaviour prior to unsaturated studies is vital especially for wastecontainment purposes. Compacted soil used for liners and covers in waste containment facilities are frequently unsaturated in the field. Rainfall and other moisture sources do not all the time fully saturate the liners and covers system as they flow. Thus, it is needful to examine the unsaturated flow that represent the actual field condition. Chiu and Shackelford [1] as well as Wang and Benson[2] reported that modelling of flow and transportation mechanism requires an adequate understanding of their unsaturated hydraulic properties. Khire et al., [3] reported that earthen landfill covers are generally unsaturated in the field and therefore require unsaturated studies. Unsaturated hydraulic conductivity (UHC) is obtained by using soilwater characteristics curve (SWCC), which correlates matric suction $(\Psi)$ with volumetric water content, $\theta$ (VWC).

Researchers [4-8] recommended a less difficult approach for assessing the hydrology of soil covers compacted in the field based on UHC. The basic idea is established on the fact that covers are mostly not fully saturated in the field after rainfall and need to be studied in that state. Also, the limited amount of rainfall in the tropical region that includes Nigeria underscores the need for actual field studies. Thus, the design of covers for landfill systems are centred on the UHC. However, in the past it was difficult to calculate the soil hydraulic performance at unsaturated phase using the empirical approach [9]. These practices encompass the application of hydraulic conductivity of saturated soil and the SWCCs. The idea of using mathematical correlations was the bestapproach with the aid of SWCC to forecast a new hydraulic conductivity. The hypothetical bases for the UHC us ed are dependent entirely on SWCCs.

Studies reported in the literature [10-12] showed that some compacted soil liners do not meet the requirement for landfill use in their natural form and need to be improved using industrial additives like cement, bitumen and lime which are relatively expensive and are not friendly to the eco-system. The use of agro-industrial wastes that exhibit pozzolanic properties are also not ecofriendly. Therefore, a sustainable mechanism that is friendly to the eco-system termed microbial-induced calcite precipitation(MICP) is desirable.

\footnotetext{
* Corresponding author: aeberemu@yahoo.com
} 
MICP is a process that encompasses carbonates production as by-product of microbial metabolic or enzyme activities of bacterial species (Bacillus coagulans). The technique entails a cementation procedure that harnesses natural subsurface soils using urea hydrolysis to induce calcite precipitation [13-18]. The calcite precipitate stiffens the soil and reduces its hydraulic properties. Several promising results have been recorded using themethod for different engineering applications [12]. This work assesses the SWCCs and UHC ofmodified lateritic soil - Bacillus coagulans using $\mathrm{BC}$ and FX models.

\subsection{Background of the study}

Unsaturated relationship in terms of water flows in soils was suggested by Fredlund et al., [9]. For an uns aturated soil, the hydraulic conductivity $(\mathrm{k})$ is a variable. Also, so many elements have definite impact on k comprising of VWC among many. Fredlund et al., [9] suggested that soil suction, which affects the properties of soil in unsaturated state, be defined as the matric suction or total suction of the soil. The authors also suggested that unsaturated soils permeability function be utilised to denote the relationship between the soil suction and the permeability coefficient. Conversely, it is worthy of note that the permeability coefficient for a defined soil suction, $\mathrm{k}(\psi)$, is linked to the saturated permeability coefficient, $\mathrm{k}_{\mathrm{s}}$, of the saturated soil. Thus, relative coefficient of permeability, $\mathrm{k}_{\mathrm{r}}(\psi)$, is determined using the expression:

$$
K_{r}(\psi)=\frac{k(\psi)}{k_{s}}
$$

In this study, $\mathrm{k}_{\mathrm{s}}$ was obtained from a falling head permeability test, while UHC was determined from model predictions that relate $\mathrm{k}_{\mathrm{s}}$ and UHC using SWCCs. However, results forecast from dissimilar models are usually inconsisitent. Such differences occurbecause it is extremely challenging to describe the UHC of s oil since it is time reliant, variable and time consuming.

The Brooks - Corey model [19], $\mathrm{k}_{\mathrm{r}}$ relative to SWCC parameters is expressed as:

$$
K_{r}= \begin{cases}1 & ; \psi \leq \psi_{a} \\ \left(\frac{\psi_{a}}{\psi}\right)^{2+3 \lambda} & ; \psi_{a}>\psi\end{cases}
$$

where $\lambda$ and $\psi_{a}$ are described as pore size distribution index and air entry pres sure in that order.

The Leong and Rahardjo [20] model for relative hydraulic conductivity forecasting, with res pect to SWCC fit parameters is expressed as [21]:

$$
K_{r}=\frac{1}{\left\{\ln \left[e+\left(\frac{\psi}{a}\right)^{b}\right]\right\}^{c}}
$$

$\theta$ can be functional in its normalized form sometimes referred to relative degree of saturation, $s$ as:;

$$
\Theta=\frac{\theta-\theta_{r}}{\theta_{s}-\theta_{r}}
$$

Where: $\Theta=$ The nomalized $\theta$ or relative degree of saturation, $\theta \mathrm{s}=$ The saturated $\theta ; \theta \mathrm{r}=$ The residual $\theta$.

Typical SWCC parameters are displayed in Figure 1

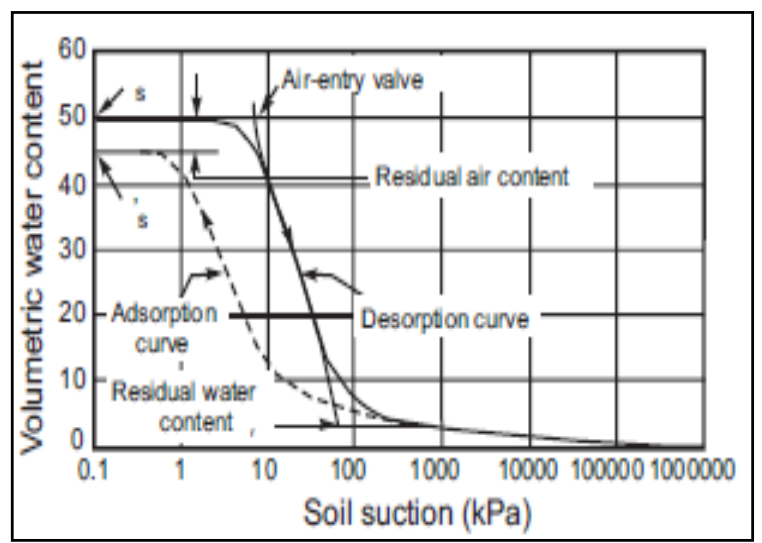

Figure 1: A typical SWCC , Source: [22]

Soils sizes affect the shape of SWCCs; thus grading of the soil plays a vital part in the understanding of flow of water in soil for containment application and in unsaturated soil studies. Soils with bigger unit sizes usually display a SWCC skewing to the left-hand of the curve accompanied by a drop in air-entry suction head, les s residual water content, les s saturated water content values [8]. Miller et al., [8], Alavijeh et al., [23] as well as Tamer et al., [24] described the SWCCs as being hysteretic, having bounding curves which explains the des orption as well as the sorption practis es. Nevertheless, normal technique used is to manage only the desorption curve because of experimental problems connected with sorption curve meas urement as defined by Tinjum et al., [25]. This curve is linked to desorption progressions only.

The Brooks and Corey [19] model for volumetric water content is expressed as:

$$
\frac{\theta_{w}-\theta_{r}}{\theta_{s}-\theta_{r}}=\left(\frac{\psi_{a}}{\psi}\right)^{\lambda}
$$

The optimized parameters include $\boldsymbol{\theta} \mathbf{r}, \boldsymbol{\psi}_{\boldsymbol{a}}$ and $\boldsymbol{\lambda}$.

The Fredlund and Xing [22] model for volumetric water content is defined as

$$
\frac{\theta_{w}-\theta_{r}}{\theta_{s}-\theta_{r}}=\frac{1}{\left\{\ln \left[e+\left(\frac{\psi}{a}\right)^{b}\right]\right\}^{c}}
$$

But, $\theta_{\mathrm{r}}$ is negligible and can be overlooked. Con sequently, equation(6) becomes equation(7):

$$
\frac{\theta_{w}}{\theta_{s}}=\frac{1}{\left\{\ln \left[e+\left(\frac{\psi}{a}\right)^{b}\right]\right\}^{c}}
$$

$a, b$ and $c$ are the optimized parameters.

\section{Materials and methods}




\subsection{Materials}

\subsubsection{Soil sample}

Disturbed sample of lateritic soil was collected from Anambra state, Nigeria at $0.5 \mathrm{~m}$ depth and placed in poly sacks.

\subsubsection{Microorganism}

B. coagulans was used for the study and was classified as ATCC 8038 [26]. The microbes were isolated from the lateritic soil using serial dilution method.

\subsubsection{Cementation reagent}

Cementation reagent composed of $3 \mathrm{~g}$ Nutrient broth, 20 g urea, $10 \mathrm{~g} \mathrm{NH}_{4} \mathrm{Cl}, 2.12 \mathrm{~g}$ of $\mathrm{NaHCO}_{3}$ and $2.8 \mathrm{~g} \mathrm{CaCl}_{2}$ per $1000 \mathrm{~cm}^{3}$ of distilled water [27]. was used in the study.

\subsection{Methods}

\subsubsection{Index properties}

Index tests were performed on untreated and treated soil as outlined in BS 1377 [28] and BS1924 [29] respectively.

\subsubsection{Preparation of soil samples}

Soil was mixed with B. coagulans at the varying suspension density of the microbes (i.e., $0,1.5 \times 10^{8}$, $6.0 \times 10^{8}, 1.2 \times 10^{9}, 1.8 \times 10^{9}$ and $2.4 \times 10^{9}$ cells $/ \mathrm{ml}$ ), prior to compaction; with about one-third of the volume of pore containing microbes [30]. Specimens were prepared with moulding water content (MWC) of $-2,0$, and $+2 \%$ relative to optimum moisture content (OMC) and compacted with British Standard light (BSL) (or standard Proctor) energy. Cementation reagent was applied to saturate the compacted soil. After treatment, a $50 \mathrm{~mm}$ diameter and $50 \mathrm{~mm}$ height cylindrical core was used to obtain specimensfrom the compacted soil in the mould. The cored specimens were immersed in a water tank to enable themget saturation via capillary action. Thereafter the saturated specimens were tested in a pressure plate extractor.

\subsubsection{Pressure application}

The method adopted for the test using the pressure membrane apparaturs (pressure plate extractor) is outlined in ASTM D3152-72 [31]. Pres sures of 0, 10,30, 100, 500, 1,000 and $1,500 \mathrm{kPa}$ were applied on the saturated specimens . Pres sure was applied (i.e.,first from $0-1,500$ $\mathrm{kPa}$ ), the arrangement is permitted to ditch out all the water till no drop of water was seen at the outlet. The specimens were then detached, weighed and again rearranged before they were subjected to pressure greater than the previous. The process was repeated for pressures up to the highest pressure value of $1,500 \mathrm{kPa}$ considered.
Thereafter, the specimens were removed from the equipment and oven-dried to determine the moisture content which was equal to their final gravimetric water content. Thetest was performed for each lateritic soil - B. coagulans mixture.

\section{Results and dis cussion}

\subsection{Index properties}

Preliminary investigations performed on the natural properties of the soil showed that the soil is fine-grained, having reddish brown colour with a natural moisture content of $11.3 \%$.. A more summary of the properties of the natural lateritic soil is given in Table 1 .

Table 1. Properties of the natural lateritic soil

\begin{tabular}{l|c}
\hline Property & Quantity \\
\hline $\begin{array}{l}\text { Percentage Passing No. 200 } \\
\text { Sieve }\end{array}$ & 35.4 \\
Natural Moisture Content, \% & 11.3 \\
Liquid Limit, \% & 37.5 \\
Plastic Limit, \% & 19.3 \\
Plasticity Index, \% & 18.2 \\
Specific Gravity & 2.62 \\
& \\
AASHTO Classification & A-4(2) \\
USCS & SC \\
& \\
Maximum Dry Density, Mg/m & \\
Optimum Moisture Content, \% & 1.83 \\
Colour & 15.3 \\
Dominant Clay Mineral & Reddish brown \\
\hline
\end{tabular}

\subsection{Impact of microbial density on SWCC model parameters}

The variation of Brooks - Corey air entry suction value $\psi_{a}$ and pore-size dis tribution factor $\lambda$ with microbial density is revealed in Table 2. The air entry $\left(\psi_{a}\right)$ values (i.e., 18 , $25,87,29,20$ and $28 \mathrm{kPa}$ ) increased and subsequently decreased with increase in B. coagulans suspension density (i.e., from 0 to $2.4 \times 10^{9}$ cells $/ \mathrm{ml}$ in that order). The initial increase may be related with the reduction in the volume of voids within the soil mass. Rowshanbakhta et al., [30] reported that air entry value is inversely interrelated to the void ratio within the soil structure. Microbial hydrolyses of urea which manufactured dissolved ammonium, inorganic carbon, as well as carbon dioxide $\left(\mathrm{CO}_{2}\right)$ led to the build-up of insoluble carbonate $\left(\mathrm{CaCO}_{3}\right)$ which may have blocked the micro pores within the soil mass $[30,32]$. In the cas e of pore size distribution factor $\lambda$, a general trend of increase (i.e., $0.739,0.304,0.633,1.150,0.698$ and 0.301 ) was observed with higher microbial suspension density (i.e., 0 to $2.4 \times 10^{9}$ cells $/ \mathrm{ml}$ in that order). The overall as sessment of these parameters show that the soil treated with $\mathrm{B}$. coagulans suspension density of $2.4 \times 10^{9} \mathrm{cells} / \mathrm{ml}$ relatively recorded the lower values, which is an indicator of improvement in the soil properties by the reduction in the pores spaces within the soil skeleton. 
For the Fredlund-Xing model, SWCC parameter $\boldsymbol{a}$ (i.e., connected to inverse of air entry value and spaces caused by the pores inside the soil matrix), parameter $\boldsymbol{b}$ (slope factor) and parameter $c$ (shape factor) with microbial density is presented in Table 2. Results largely showed an increase in parameters $\boldsymbol{a}$ (i.e., 46, 245, 260, 53, 54, and 280) and $\boldsymbol{b}$ (i.e., 0.049, 0.135, 0.216, 0.076, 0.074, and 0.092 ) values with increase in B. coagulans suspension dens ity up to $2.4 \times 10^{9}$ cells $/ \mathrm{ml}$. Parameter $\boldsymbol{b}$ that govems the slope of SWCCs increased with increase in microbial density, however, parameter c,(i.e., 5.621, 0.089, 2.786, $4.013,2.672$ and 0.928 ) which is related to residual water content decreased with higher microbial density. The increase in matric suction could probably be due to domination of smaller-pores in the soil matrix at higher MWC, and thus a decrease in $c$. value. This is in agreement with findings reported by Fredlund and Xing [22] and Fredlund et al., [33].

Table 2. Brooks - Corey ( $\psi_{\mathrm{a}}$ and $\left.\lambda\right)$ and Fredlund-Xing ( $a, b$ and $c$ ) SWCC parameters with microbial density

\begin{tabular}{|c|c|c|c|c|c|}
\hline \multirow{3}{*}{$\begin{array}{c}\text { B. } \\
\text { coagulans } \\
\text { suspensio } \\
\text { n density } \\
\text { cells } / \mathrm{ml}\end{array}$} & \multicolumn{2}{|c|}{$\begin{array}{c}\text { Brooks-Corey model } \\
\text { parameters }\end{array}$} & \multicolumn{3}{|c|}{$\begin{array}{l}\text { Fredlund -Xing's } \\
\text { model parameters }\end{array}$} \\
\hline & \multirow{2}{*}{$\begin{array}{c}\text { Air } \\
\text { Entry } \\
\text { pressure } \\
\psi_{\mathrm{a}}(\mathrm{kPa})\end{array}$} & \multirow{2}{*}{$\begin{array}{l}\text { Pore-size } \\
\text { distribution } \\
\text { index }, \lambda\end{array}$} & \multicolumn{3}{|c|}{ Parameters } \\
\hline & & & $a$ & $b$ & $c$ \\
\hline 0 & 18 & 0.739 & 46 & 0.049 & 5.621 \\
\hline $1.5 \times$ & 25 & 0.304 & 245 & 0.135 & 0.089 \\
\hline $6.0 \times 10^{8}$ & 87 & 0.633 & 260 & 0.216 & 2.786 \\
\hline $1.2 \times 10^{9}$ & 29 & 1.150 & 53 & 0.076 & 4.013 \\
\hline $1.8 \times 10^{9}$ & 20 & 0.698 & 54 & 0.074 & 2.672 \\
\hline $2.4 \times 10^{9}$ & 28 & 0.301 & 280 & 0.092 & 0.928 \\
\hline
\end{tabular}

\subsection{A comparative result of SWCC}

A comparative result of SWCC for measured values and the predicted ones using BC and FX models are dis played in Figures 2a-f. Generally, it was noticed that with increase in matric suction from $10-1,500 \mathrm{kPa}$, the VWC decreased gradually for the models and the measured results. For the natural soil, the VWC laboratory measured values of $0.146,0.143,0.139,0.138,0.135$ and 0.133 were obtained for matric suctions of $10-1,500 \mathrm{kPa}$. BC model recorded $0.1476,0.1447,0.142,0.140,0.139$ and 0.138 formatric suctions of $10-1,500 \mathrm{kPa}$. In the case of FX model, values of $0.1460,0.1459,0.1452,0.1444$, 0.1443 and 0.1442 were obtained for matric suctions of $10-1,500 \mathrm{kPa}$. Similar pattern was observed for all microbial densities used in the study.

Furthermore, the models overestimated the VWC with greatervalues than the measured results. However, the $\mathrm{BC}$ model overestimated the VWC at lesser matric suction over FX model for the microbial densities considered. With an increase in matric suction beginning from 30 up to $1,500 \mathrm{kPa}, \mathrm{FX}$ model overestimated the VWC over the $\mathrm{BC}$ model. Although, the residual VWC ( $\theta \mathrm{r})$ did not follow the usual path of over and under approximation when likened to the measured SWCC values as stated in past research works i.e.,[1,8,25,34-36],a decrease in VWC was observed with increase in matric suction.
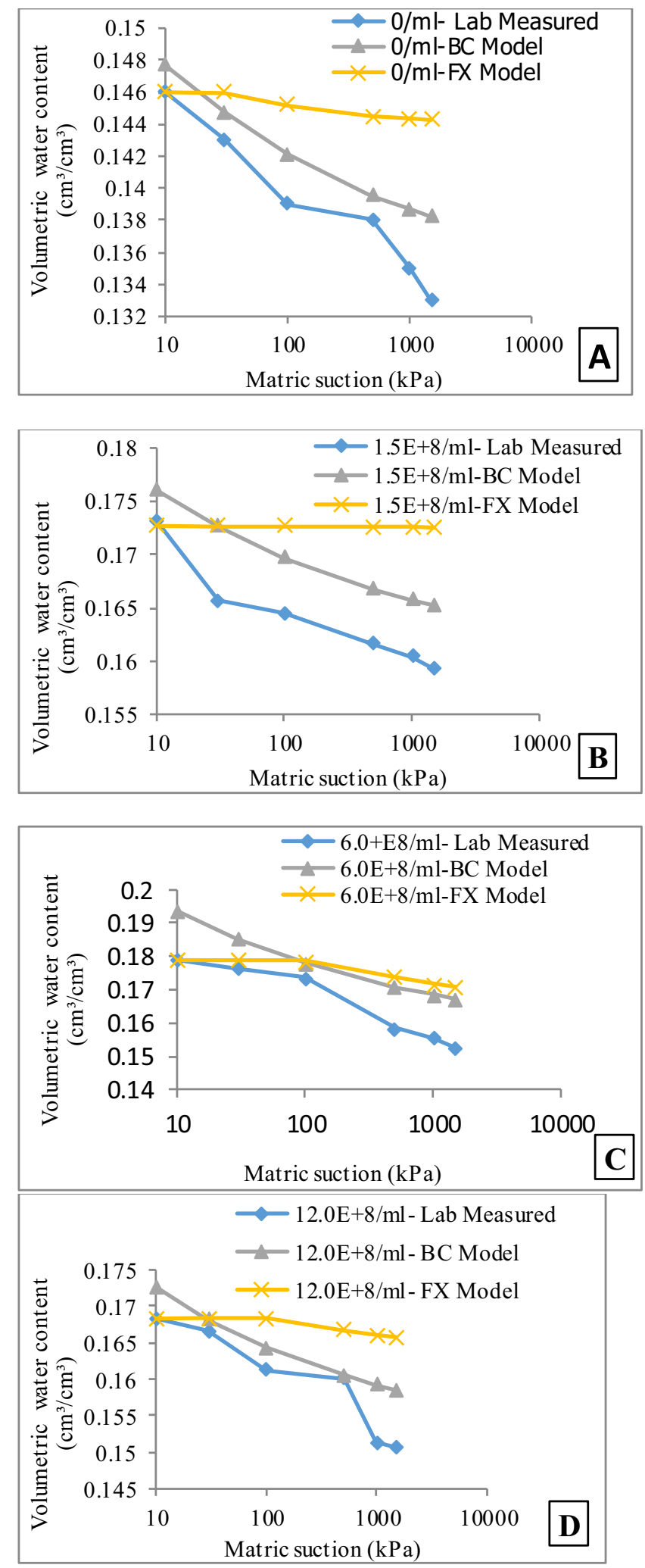

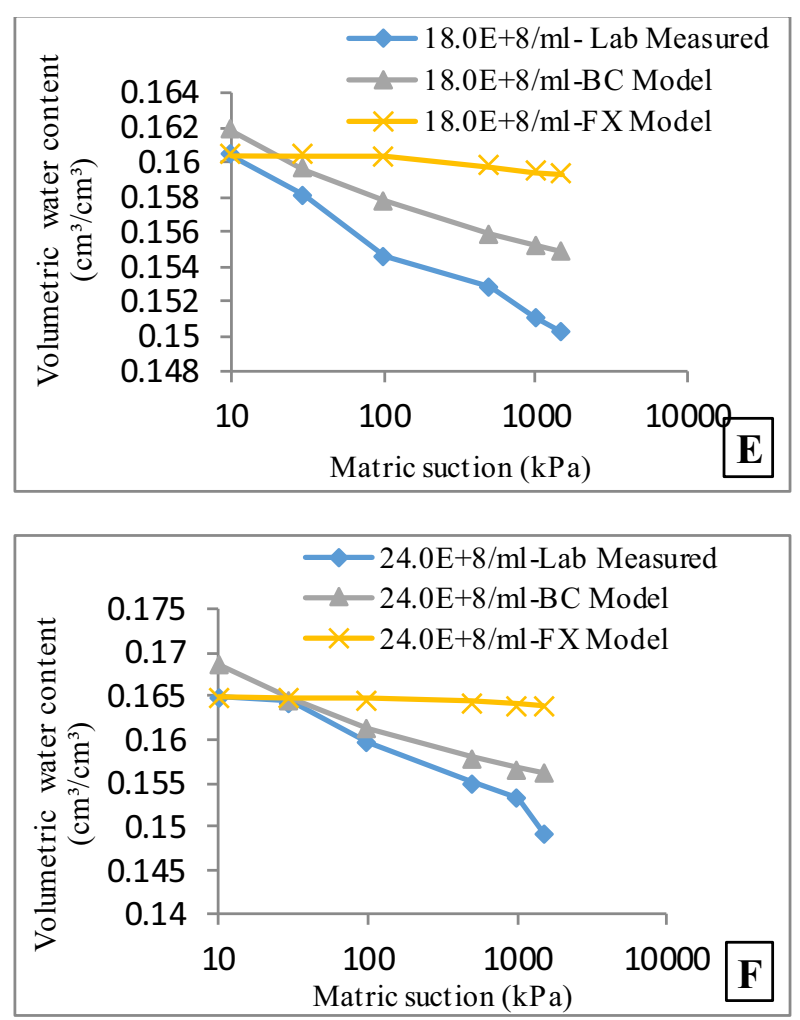

Figure 2. Measured and modelled SWCCs for varying microbial density (A) 0 cells $/ \mathrm{ml}$ (B) $1.5 \times 10^{8}$ cells $/ \mathrm{ml}$ (C) $6.0 \times 10^{8}$ cells $/ \mathrm{ml}$ (D) $1.2 \times 10^{9}$ cells $/ \mathrm{ml}$ (E) $1.8 \times 10^{9}$ cells $/ \mathrm{ml}$ (F) $2.4 \times 10^{9}$ cells $/ \mathrm{ml}$.

\subsection{Impact of microbial density on unsaturated hydraulic conductivity (UHC)}

The variations of unsaturated hydraulic conductivity (UHC) with B. coagulans suspension density for samples prepared at $\mathrm{OMC}$ and compacted with BSL energy predicted using BCand $\mathrm{FX}$ models for matric suctions of 500 and $1500 \mathrm{kPa}$ is shown in Figure 3. The UHC predicted for matric suctions of 500 and $1,500 \mathrm{kPa}$ initially decreased from 0 up to $1.2 \times 10^{9}$ cells $/ \mathrm{ml}$ for both $\mathrm{BC}$ and FX models with the exception of a few cas es and thereafter increased with increase in microbial density. For BC model at $1,500 \mathrm{kPa}$, UHC values of $2.26 \times 10^{-17}$, $1.41 \times 10^{-14}, 2.2 \times 10^{-14}, 4.6 \times 10^{-19}, 3.25 \times 10^{-17}$ and $2.45 \times 10^{-}$ ${ }^{14} \mathrm{~m} / \mathrm{s}$ were recorded at B. coagulans suspension density of $0,1.5 \times 10^{8}, \quad 6.0 \times 10^{8}, 1.2 \times 10^{9}, \quad 1.8 \times 10^{9}$ and $2.4 \times 10^{9}$ cells $/ \mathrm{ml}$, respectively. In the case of FX model, at 1,500 $\mathrm{kPa}$, UHC values of $2.42 \times 10^{-9}, 2.02 \times 10^{-9}, 9.31 \times 10^{-10}$, $8.09 \times 10^{-10}, 1.29 \times 10^{-9}$ and $2.27 \times 10^{-9} \mathrm{~m} / \mathrm{s}$ were recorded at $0,1.5 \times 10^{8}, \quad 6.0 \times 10^{8}, 1.2 \times 10^{9}, \quad 1.8 \times 10^{9}$ and $2.4 \times 10^{9}$ cells $/ \mathrm{ml}$ in that order. As microbial density increased, formation of more calcites as product of MICP process may possibly be the reason for the decrease in UHC value. Also, soil particles binding and the clogging of openings in the soil skeleton as calcite are formed to fill such spaces led to less ening of the UHC. Abo-El-Enein et al., [37], Muthukkumaran and Bettadapura[38], Chi et al.,[17].) reported similar results.

The FX model satisfied the design maximum hydraulic conductivity value of $1 \times 10^{-9} \mathrm{~m} / \mathrm{s}$ for waste containment system for B. coagulans suspension density of $1.2 \times 10^{9}$ cells $/ \mathrm{ml}$ treatment of lateritic soil, while BC model which met the requirement at all the microbial suspension densities considered is recommended for use in modelling the UHC of the modified soil. The recorded finding shows that $\mathrm{BC}$ model has a more promising outcome in determining UHC in the field than FX model. Thus, these results should be carefully applied under field conditions in order to achieve the desired output. A lso, adequate microbial density as achieved in the laboratory should be used in the field to achieve the target UHC values as specified in the literature.

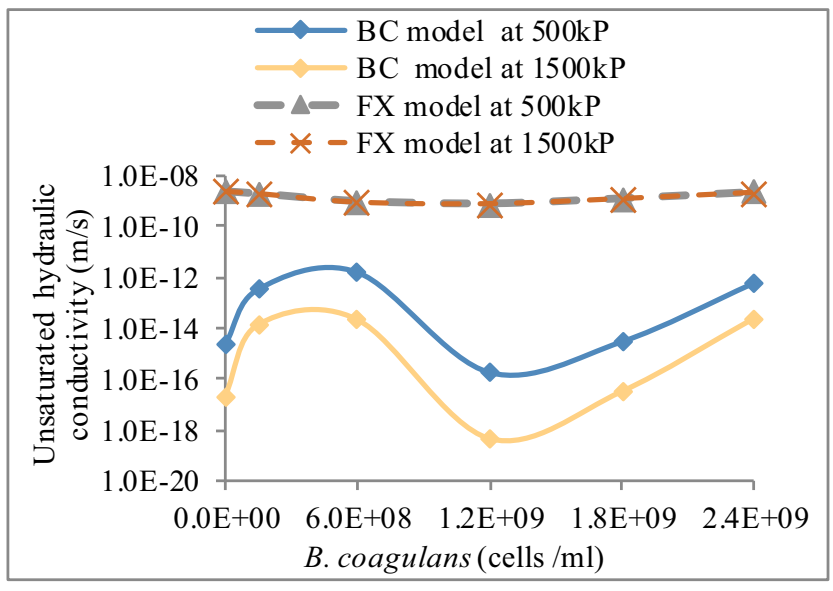

Figure 3. Plot of UHC with microbial density/ml based on Brooks-Corey (BC) and Fredlund-Xing (FX) models at 500 and $1500 \mathrm{kPa}$ matric suctions.

\section{Conclusion}

A comparative study of SWCCs for compacted lateritic soil - B. coagulans mixtures was carried out. Based on the laboratory and model outputs, the following conclusions can be made:

1. Generally, BC and FX models overestimate the volumetric water content (VWC). Also, the VWC reduced with higher matric suction for the measured and modelled values.

2. The unsaturated hydraulic conductivity (UHC) predicted for matric suctions of 500 and 1,500 $\mathrm{kPa}$ initially decreased from 0 up to $1.2 \times 10^{9}$ cells $/ \mathrm{ml}$ for both $\mathrm{FX}$ and $\mathrm{BC}$ model with the exception of a few cas es and thereafter increased with increase in microbial suspension density.

3. For FX model at $1,500 \mathrm{kPa}$, UHC values of $2.42 \times 10^{-9}$ and $2.27 \times 10^{-9} \mathrm{~m} / \mathrm{s}$ were recorded at $\mathrm{B}$. coagulans suspension densities of 0 and $2.4 \times 10^{9}$ cells $/ \mathrm{ml}$, respectively. In the case of BC model, values of $2.26 \times 10^{-17}$ and $2.45 \times 10^{-14} \mathrm{~m} / \mathrm{s}$ were recorded at 0 and $2.4 \times 10^{9} \mathrm{cells} / \mathrm{ml}$.

4. The FX model satisfies the design maximum hydraulic conductivity value of $1 \times 10^{-9} \mathrm{~m} / \mathrm{s}$ for waste containment system at $\mathrm{B}$. coagulans suspension density of $1.2 \times 10^{9}$ cells $/ \mathrm{ml}$, while the $\mathrm{BC}$ model met the requirement at all for all $\mathrm{B}$. coagulans suspension density considered and therefore it is recommended for modelling the UHC of the modified lateritic soil for municipal solid waste containment application. 


\section{References}

1. T.F. Chiu \& C.D. Shackelford (1994) Practical as pects of the capillary barrier effect for landfills. Proc. 17th Annual Madison Waste Conf. Dept. of Engrg. Prof. Dev., Univ. of Wisconsin, Madison, Wis., 357-365.

2. X. Wang \& C.H. Benson(1995)Infiltration and saturated hydraulic conductivity of compacted clay. $J$. of Geotech Engrg, ASCE,121(10),713-22.

3. M. Khire, C. Benson \& P. Bosscher (1997) Water balance modeling of earthen final covers at humid and semi-arid sites. J. Geotech. Engrg., ASCE, 123 (8), 744-754.

4. M.V. Khire, C.H. Benson, P.J. Boscher \& R.J. Pliska (1994).Field - scale comparison of capillary and resistive barriers in an arid climate Procs 14th Annual Amer Geophys. Union Hydrol Days, H.J. MorelSeytoux, ed., Colorado State Uni, Fort Collins, Colo., 195-209.

5. M.V. Khire, J.S. Meerdink, C.H. Benson \& P.J. Bosscher (1995). Unsaturated hydraulic conductivity and water balance predictions for earthen landfill final covers' Soil suction appls in Geotech Eng prac, W.K. Wray \& S.L. Houston, eds., A.S.C.E., 35-57.

6. T.F. Chiu, \& C.D. Shackelford (1998). Unsaturated hydraulic conductivity of compacted sand-kaoline mixtures, J. of Geotech. \& Geo. Eng, A.S.C.E., 24(2), 160-170.

7. J.S. Meerdink, C.H. Benson \& M.V. Khire, (1996). Unsaturated hydraulic conductivity of two compacted barrier soils. J. of Geotech Eng. A.S.C.E., 122(7), 565576.

8. C.J. Miller, N. Yesiller, K. Yaldo \& S. Merayyan (2002). Impact of soil type and compaction conditions on soil water characteristics $J$. of Geotech \& Geoenviron Eng.128(9), 733 - 742.

9. D.G. Fredlund, A. Xing \& S. Huang (1994) Predicting the permeability function for unsaturated soils using the soil-water characteristic curve. Can Geotech J. 31(3), 521-532.

10. A.O. Eberemu, A.A. Amadi \& K.J. Osinubi. (2013) The use of compacted tropical clay treated with rice husk ash as a suitable hydraulic barrier material in waste containment application' Was \& Biom 4, (2),309 -323 .

11. K.J. Osinubi, A.O. Eberemu, \& A.A. Amadi, (2012). Compatibility of compacted lateritic soil treated with bagasse ash and municipal solid waste leachate' Int $J$. of Env \& Waste Man (IJEWM) 10(4),365376.Inders cience Publishers Ltd., United Kingdom.

12. K. J. Osinubi, A.O. Eberemu, T.S. Ijimdiya \& P. Yohanna. (2020) Interaction of Landfill Leachate with Compacted Lateritic Soil Treated with Bacillus coagulans Using Microbial-Induced Calcite Precipitation Approach. J. of Haz, Tox, \& Rad Waste. ASCE

DOI: 10.1061/(ASCE)HZ.2153-5515.0000465.

13. J.T. DeJong, M.B. Fritzges \& K. Nusslein (2006) Microbial induced cementation to control sand response to undrained shear. ASCE J. Geotech \& Geoenviron. Engng 132(11), 1381-1392.
14. B.L. Banagan, B. M. Wertheim, M. J.S. Roth \& L.F.Caslake (2010)Microbial strengthening of loose sand.Lett.Appl. Microbiol.51(2), 138-142.

15. J. K. Firas \& Z. Jun-Jie (2017)Influences of Calcium Sources and Type of Sand on Microbial Induced Carbonate Precipitation Int $J$. of $A d v$ in Engng \& Tech.10(1),20-29.

16. R. M. P. Carla, F. Carolyn, C.M. Carlos, M. Richard \& J. Todd (2020) Microbiologically Induced Calcite Precipitation biocementation, green alternative for roads - is this the breakthrough? A critical review. $J$. ofClea product.

https://doi.org/10.1016/j.jclepro.2020.121372.

17. L. Chi, Y. De, L. Shihui, Z. Tuanjie, B. Siriguleng, G. Yu \& L. Lin(2017) Improvement of Geomechanical Properties of Bio-remediated Aeolian Sand, Geomicrogy $J, \quad$ DOI: 10.1080/01490451.2017.1338798.

18. A. Erdal, B. Omer \& M.D. Nazime(2017) Strengthening sandy soils by microbial methods. Arabn J. of Geosci.

DOI 10.1007/s 12517-017-3123-9.

19. R.H Brooks \& A.T. Corey(1964). Hydraulic properties of porous media. Colorado State University, Hydrology Paper. 3, Fort Collins, Colorado.

20. E.C. Leong \& H. Rahardjo (1997). Review of soil water characteristic curve equations', J. of Geotech\& Geoenviron Engrg, A.S.C.E., 123(12).

21. M. Gui, C. Wu \& C. Lu (2011) Comparis on of Two Water Storage Functions of Soil on Porewater Pressure of Earth-Filled Dam under Changing Environment" Proc of the 28th Int Assoc for Autom and Robot in Construn, ISARC ,Seoul Korea, 534543.

http://www.iaarc.org/publications/fulltext/S15-7.pdf.

22. D.G. Fredlund \& A. Xing (1994).Equations for the Soil-Water Characteristic Curve. Can Geotech J, 31(4),521-532. DOI:10.1139/t94-061.

23. B.G. Alavijeh, A. Liaghat, H. Guan-Hua \& M. T. Van genuchten, (2010) Estimation of the van Genuchten Soil Water Retention Properties from Soil Textural Data. J. ofPedo 20 (4), 456-465.

24. Y. E. Tamer, A.Ahmed, D.Muawia \& A. Mosleh (2017)Effect of compaction state on the soil water characteristic curves of sand-natural expansive clay mixtures, Eur J. of Environtl and Civ Engng, 21:3, 289-302.

25. J. M. Tinjum, C.H. Benson, \& L.R Blotz. (1997).Soilwater characteris tic curves for compacted clays. J. of Geotech \& Geoenvron Engng. 123(11),1060-1069.

26. ATCC(2013).American Type Culture Collection P.O Box 1549 Manassas, VA 20108 USA. http://www.atcc.org.

27. S. Stocks-Fischer, J.K. Galinat, \& S.S Bang. (1999). Microbiological precipitation of $\mathrm{CaCO}_{3}$. Soil Bio and Biochem 31 (11),1563-1571.

28. BS 1377, (1990). Methods of Testing Soil for Civil Engineering Purposes. British Standards Institute, London.

29. BS 1924, (1990). Methods of Test for Stabilized Soils. British Standards Institute, London. 
30. K. Rowshanbakhta, M. Khamehchiyana, R.H. Sajedib \& M.R. Nikudela,(2016) Effect of Injected Bacterial Suspension Volume and Relative Density on Carbonate Precipitation Resulting from Microbial Treatment. J. of Ecol Engng, 89, 49-55 https://doi.org/10.1016/j.ecoleng.2016.01.010.

31. ASTM (1994). Standard test method for capillary moisture relationships for fine-textured soils by pres sure membrane apparatus' Designation: D 315272. West Conshohocken, Pa.

32. H. Rong \& C. Qian (2013)Microstructure Evolution of Sands tone Cemented by Microbe Cement Using X-ray Computed Tomography Journal of Wuhan University of Technology-Mater. Sci. 28 (6),11341139 DOI 10.1007/s 11595-013-0833-Z.

33. D. G. Fredlund, D.Sheng, \& J. Zhao(2011) Estimation of Soil Suction from the Soil-Water Characteristic Curve.Can GeotechJ. 48,186-198.

34. C. M. O Nwaiwu (2004) CompactedLateritic Soils as Hydraulic Barriers in Municipal Solid Waste Containment systems. A PhD diss ertation presented to the Postgraduate School, Ahmadu Bello Univ, Zaria, Nigeria.

35. J.R Oluremi (2015) Evaluation of Waste Wood ash Treated Lateritic Soil for Use in Municipal Soild Waste Containment Application An unpublished Ph.D dissertation presented to the Postgraduate School, Ahmadu Bello Univ, and Zaria, Nigeria.

36. A.R. Osim (2017) Compacted Cement Kiln Dust Treated Black Cotton Soil as Suitable Liner and Cover Material in Waste Containment Facilities. An unpublished Ph.D dissertation presented to the Postgraduate School, Ahmadu Bello Univ, Zaria, Nigeria.

37. S.A. Abo-El-Enein, A.H. Ali, F. N. Talkhan, \& H.A. Abdel-Gawwad,(2012)Utilization of Microbial Induced Calcite Precipitation for Sand Consolidation and Mortar Crack Remediation. J. of Houng \& Buildng Natl Res Cente, 8, 185-192.

38. K. Muthukkumaran \& S.S. Bettadapura. (2016). Durability of microbial Induced Calcite Precipitation (MICP ) treated cohesionless soil. Jap geotech socie, 2(56), 1946-1949.

doi:10.3208/jgssp.IND-23. 